\title{
The Growth-Inducing Impact of Nigeria Capital Market on the Agricultural Sector
}

\author{
N.R Uwajumogu $(\mathrm{PhD})^{1}{ }^{1}$ I.C Ogbonna ${ }^{1}$, G. Chijioke ${ }^{2}$, S.V Agu ${ }^{3}$ \\ ${ }^{\prime}$ (Department of Economics, Renaissance University, Ugbawka, Enugu State, Nigeria) \\ ${ }^{2}$ (Department of Banking and Finance, Renaissance University, Ugbawka, Enugu State, Nigeria) \\ ${ }^{3}$ (Department of Economics, Enugu State University of Science and Technology, Agbani, Enugu State, Nigeria)
}

\begin{abstract}
The capital market performs many roles that are critical for the growth and development of an economy. Such roles include liquefying the economy, efficient allocation of resources, pooling of savings and reducing risk etc. There is paucity of capital in developing countries like Nigeria, thus the need to enhance the capital market. Despite the increased activities in the capital market, the real sectors of the economy are not feeling the impacts of these activities. The study was aimed at finding out whether the capital market has growth-inducing impact on the agriculture sector. The study employed co-integration techniques to achieve this purpose using time series data sourced from CBN bulletin from 1980-2012. The study found that capital market measures had statistically insignificant impact on agricultural output long run. This implies that despite the expanded activities in the Nigerian capital market over the years, there has not been any remarkable impact on the real sectors of the economy. On the basis of these findings some of these recommendations were proffered: removal of the impediments to the growth of agricultural sector; reduce the cost of doing business in Nigeria; there should be transparency in policy formulation and implementation etc.
\end{abstract}

Keywords : capital market, co-integration, growth-inducing, liquefying, time-series

\section{Introduction}

Economists, over time have bothered on the reasons why some economies grow while others do not or why economies grow at all. It is broadly accepted that economic growth and standard of living is higher today than so many years back and this can be attributed to the advanced state and level of technology. However, historical evidence and records shows that technological progress is not new but has been there since the beginning of recorded history. Colander (2004 [1]) identified five waves of technological innovations that have driven the global economy since the late $16^{\text {th }}$ Century. The first wave was between 1785 and1835 and led to development of steam power and iron manufacturing. The second wave was from 1835 to 1885 which led to railroad construction, mobile steam power and steam shipping. Development of chemicals, electricity, telegraph, telephone and automobiles was in the third wave which was from 1885 to 1935 . Electronics, drugs, oil, air transport, computers and nuclear power were the important technological advances in the fourth phase from 1935 to 1985 . The fifth phase which started from 1985 to the present day has led to the development of genetic engineering, telecommunications and biotechnology.

But despite all these development in technology over ages, there was no noticeable difference and improvement on economic growth and general standard living until 1800 (Andolfatto, 2005 [2]). But since then, most economies have exhibited at least some growth in per capita incomes, but for many economies that are today's world's underdeveloped nations, growth rates have been relatively low, leaving their per capita income levels far behind the leading economies of the world. Seminal work by Romer argued that human capital development is important for economic growth and per capita income growth.

Colander (2004) identified some critical institutions that are essential for acquiring human capital and engaging in research and development, notable among them is the financial institution. This, agreed with works by Schumpeter (1934 [3[), King and Levine (1993 a [4] \& b [5]), Goldsmith (1969 [6]), McKinnon (1973 [7]) and Shaw (1973 [8]) that buttressed the importance of finance and financial institutions in economic growth and development. The major implication of these works cited above is that for a country to grow, the financial sector and its institutions must be developed, deepened and efficient.

One importance role of the financial institution is to intermediate between the surplus sector of the economy and the deficit sector of the economy. It does this by reducing the costs of cost information, transaction and monitoring; promoting productive investment through funding; mobilizing both domestic and foreign saving and monitoring business investment performance. The institution also facilitates exchange of goods and services and enables trading, hedging and diversification of risks. These functions allow scarce resources to be allocated efficiently and effectively to their most productive use in increased accumulation of 
physical and human capital, faster technological progress and rapid engagement in research and development. These increase income and economic growth.

The capital market is one important subset of the financial sector whose role is critical for economic growth and development. The capital market is a market for obtaining long-term fund and also performs all the critical roles performed by a financial institution. The finance literature is replete with the critical role of financial market liquidity in affecting the efficiency of physical production. Hicks (1969 [9]) opined that it was not new technological inventions that started the wave of industrial revolution in England in the eighteenth century. He noted that most of the innovations that characterized the early phases of the industrial revolution had been invented much earlier. Rather, more liquid financial markets made it possible to develop projects that required large capital injections for long periods before the projects ultimately yielded profits. Most profitable investments require long gestation period to mature and long term commitment of capital but most savers and investors are not willing to part with their savings for a long time. The capital market solves this problem by creating liquidity (Adenuga, 2010 [10]). Liquidity is created when savers are provided with easily convertible financial assets in form of equities and businesses have easier and permanent access to large pool of funds which are raised by issuing equities (Adenuga, 2010 [10]). Thus, without liquid markets, savers would have been less willing to invest in the large, long term projects that characterized the industrial revolution. Bencivenga, et al (1996[11]) goes as far as stating that "the industrial revolution therefore had to wait for the financial revolution."

It is in recognition of this critical role of capital market on economic growth that the government of Nigeria has over years sought to develop and strengthen this market. From a modest start in 1977 as an off-shoot of the Lagos Stock Exchange, the Nigerian Stock Exchange (NSE) has grown in width, size and depth. According to CBN (2010 [12]), the value of the total annual market capitalization was N5.0 billion in 1981 and it maintained a steady increase up to 1996 when it was valued at N285.8 billion. After this year, there was a dip in the value for the two succeeding years and the market capitalization picked up. It attained its pick in 2007 when it was valued at N13, 294.6 billion.

From available statistic (CBN, 2010), the number and value of deals have also increased. In 1981, the total number of deals was 10,199 valued at N304.8 million. The total number of deals was 256,523 valued at N28, 153.1 million the year 2000. The number and value of deals peaked in 2008 when the number of deals was $3,535,631$ and valued at N1, 679,143.7 million. By the end of 2010, there were (ten) trading centers and most indicators of capital market development have shown remarkable growth and resilience.

Juxtaposing this remarkable improvement on the Nigerian economy leaves much to be desired, most especially in the real sectors of the economy. While indices of the capital market and the banking sector show remarkable improvement, the same cannot be said of the real sectors which have been recognized as the main driver of sustainable growth. Thus, the subject of the research is to answer the pertinent question of whether capital market has growth inducing impacts on the agricultural sector of the economy. In order to answer this critical question, the research hypothesis is stated as follows: The Nigerian Capital Market has no growthinducing impact on the agricultural sector between the period 1980 and 2012.

The foregoing is the introduction. The next section reviewed the theoretical and empirical literature on the impact of capital market on economic growth. Section three discussed the data and method used in the conduct of the research, while section four presented and analyzed the results. The last section dealt with the conclusion and recommendations from the findings of the study.

\section{Theoretical Framework: Capital Market And Economic Growth}

The capital market is in the focus of the economist and policy makers because of the inherent gains it provides for the economy. The stock market provides the pivot for capital market activities and it is often cited as a indicator of the soundness or otherwise of business activities in an economy (Obadan, 1998 [13]).

The stock market is viewed as a complicated institution that has in-built system that mobilizes longterm funds from the major players in the economy - households, firms, and government and directs this fund to the various sectors of the economy (Nyong, 1997 [14]). Several scholars have directed searches on the relationship between the development of the financial system and the economic growth.

On one side is the view that stock markets promote long-run growth. Stock market contributes to economic growth through the specific services it performs either directly or indirectly. Notable among the functions of the stock market are mobilization of savings, creation of liquidity, risk diversification, improved dissemination and acquisition of information, and enhanced incentive for corporate control. Improving the efficiency and effectiveness of these functions, through prompt delivery of their services can accelerate the rate of economic growth. Stock markets reduce the cost of saving mobilization, direct investments into their most productive use Greenwood and Smith (1997 [15]). Obstfeld (1994 [16]) shows that international risk sharing through internationally integrated stock markets improves resource allocation and accelerates growth. Bencivenga, et. al. (1996 [11]) and Levine (1991 [17]) have argued that the ability of the stock market to trade 
equity easily plays a key role in economic growth. Investments that are profitable usually requires long term outlay of capital but savers who supply this fund would not like to relinquish control of their savings for long periods without enough guarantee. Liquid stock markets solve this problem by providing savers with financial assets that are easily convertible while at the same time providing access to long term finance for investors. Liquidity has also been argued to increase investor incentive to acquire information on firms and improve corporate governance (Kyle, 1984 [18]; Holmstrom and Tirole, 1993 [19]), thereby facilitating growth.

Another related function of the stock market is the risk diversification function especially when the stock market is integrated globally. This enables potential and actual investor have diverse investment portfolio and thus, reduce the risks they may face. Usually, investments that earn high return are often riskier and with this risk diversification function of the capital market, high-return projects can be embarked on. (Obstfeld, 1994 [16]). This acts as a boost to the economy leading to growth as many high-return projects are now embarked on. Accelerated economic growth may also result to acquisition of information about firms. Rewards often come to an investor able to trade on information, obtained by effective monitoring of firms for profit. This also serves as early-warning sign to investors on potential distressed firms. Thus, improved information will improve resource allocation and promote economic growth.

At any stage of a nation's development, both the government and the private sectors would require long-term capital. For instance, companies would need to build new factories, expand existing ones, or buy new machinery. Government would also require funds for the provision of infrastructures. All these activities require long-term capital, which is provided by a well functioning stock market.

The nature and economic significance of the relationship between stock market development and growth vary according to a country's level of economic development. The proponents of positive relationships between stock market development and economic growth hinged their argument on the fact that the stock market aids economic growth and development through the mobilization and allocation of savings, risk diversification, liquidity creating ability and corporate governance improvement among others. Nyong (1997[14]) reported that as far back as 1969 Goldsmith observed that the emergence of equity markets and its rapid development indicate the level of economic growth and development.

On the other hand, some views cast doubts on the contribution of stock markets to long-run growth. For example, the role of stock markets in improving informational asymmetries has been questioned by Stiglitz (1985 [20]) who argues that stock markets reveal information through price changes rapidly, creating a freerider problem that reduces investor incentives to conduct costly search. The contribution of liquidity itself to long-term growth has been questioned. Demirguc-Kunt and Levine (1996[21]) point out that increased liquidity may deter growth via three channels. First, it may through income and substitution effects, decrease saving rates. Second, by reducing the uncertainty associated with investments, greater stock market liquidity may reduce saving rates because of the ambiguous effects of uncertainty on savings; third, stock market liquidity encourages short-sightedness on the part of the investor, adversely affecting corporate governance and thereby reducing growth.

However, Jensen and Murphy (1990 [22]) had contrary view on the impact of stock market on corporate governance. They believed that when managers' compensation are tied to the performance of stocks, it reduced the agency problems between agents and principals, thereby triggering off efficient resource allocation and economic growth.

\subsection{Empirical Literature}

Many empirical studies have been conducted on the impact of the capital market on economic growth in Nigeria and other economies but the controversy raged on as the findings were mixed. While some studied found that capital markets have positive impact on economic growth, others found a negative impact and others found no impact at all. The results of the other studies were mixed depending on the stock market variables used in the study.

Kolapo and Adaramola (2012, [23]) using Johansen cointegration and causality conducted a study on the impact of the Nigerian capital market on economic growth between 1990 and 2010. The Johansen test found that a relationship exists between capital market and economic growth in Nigeria. The causality test found bidirectional causation between GDP and the values of transactions while a unidirectional causality from market capitalization to GDP and not vice versa. They found that there is no causation between GDP and total new issues as well as GDP and total listed equities and government stocks.

Usman (2012, [24]) conducted a research also aimed at finding the impact of capital market on economic growth in Nigeria between 1980 and 2008 using OLS. The impact of the individual stock market variables on economic growth differed. While the share index and transactions at the stock exchange each had negative and significant impact on GDP; market capitalization and turnover ratio each had positive and significant impact on GDP. These stock market variables together caused about $84 \%$ variation in GDP. This 
study is criticized on the ground that there was no test for unit root, thus the possibility of the result being spurious is high.

Ihendinihu and Onwuchekwa (2012, [25]) examined the impact of stock market performance on economic growth in Nigeria using annual data from 1984-2011. They constructed a model with Gross Domestic Products as proxy for economic growth while Market Capitalization, Value of Transaction, All-Share Index and Total Listed Companies served as predictor variables. Their results show that in the short-run about $88 \%$ of the changes in the GDP can be explained by the chosen capital market indicators. Market Capitalization and previous year All-Share Index are shown to have significant positive effects on GDP. Value of Transactions is shown to be significant and negatively correlated with GDP. However, total number of listed companies is shown to have negative and insignificant effect on economic growth in the short run. The long-run effect indicates that the selected stock market performance measures had improved predictive powers, accounting for about $95 \%$ of the changes in economic growth as against about $88 \%$ achieved in the short-rum. Only two of the capital market variables market capitalization and values of transactions were significant predictors of economic growth. While MKTCAP is positively correlated with GDP, VALTRAN is shown to be inversely related.

Using vector error correction model, Adenuga (2010[10]) studied the impact of stock market development in Nigeria using quarterly data from 1990 to 2009. In each of the three models he used, different indicators such as value of shares traded ratio, market capitalization ratio and turnover ratio were used to capture stock market development. Finding of the study shows that each of the three indicators of stock market indicators was positively and significantly related to economic growth.

A study by Barna and Mura (2010, [26]) using data from Romania between 2000 and 2009 found that economic growth had a positive and significant impact on stock market index. The stock market index was measured by BET which is an index weighted by market capitalization and is designed to reflect the overall trend in price of ten most liquid shares traded on the Bucharest Stock Exchange. Data for the study was analyzed using simple OLS regression and found that $77.8 \%$ variation in stock market is explained economic growth. This study is criticized on the ground that using simple OLS to capture the impact of economic growth alone on the stock market is too simple to capture all the complexities in stock market determination.

Brasoveanu et al $(2008,[27])$ studied correlations between capital market and economic growth for Romania using quarterly data from $2000-2006$. Their methods of analysis were regression and VAR and their results show that economic growth and capital market indicators (real market capitalization and trading volumes in real values) were separately positively correlated with feed-back effects but the strongest link is from economic growth to capital market.

Donwa and Odia (2010, [28]) aimed to empirically analyze the impact of the Nigerian capital market (market capitalization, total new issues, value of transactions and total listed equities and government stock) on her socio-economic development proxy by GDP using data from 1981-2008. Using OLS, they found that market capitalization and value of transactions have positive and insignificant impact on socio-economic development; while total new issues have negative and insignificant on socio-economic development. On the hand, total listed equities and government stock have positive and significant impact on socio-economic development. Their results show that capital market has potentials for growth-inducing but has not contributed meaningfully to economic growth.

A similar result was obtained by Oke and Adeusi (2012, [29]) who studied the impact of capital market reforms on Nigeria's economic growth from 1981 to 2010. They used different indicators of capital market (such as market capitalization, all shares index, total new issues, total value of transactions and number of deals) to assess the impact of reforms in the capital market on economic growth proxy by GDP while controlling for inflation. The Johansen co-integration test shows that in the long run, market capitalization and number of deals had positive and insignificant relationships with GDP while all shares index, total new issues and total value of transactions had negative and insignificant relationships with GDP. Using ECM, in the short run, market capitalization had positive and insignificant relationship with GDP but total value of transactions had positive and insignificant relationships with GDP. On the other hand number of deals, all shares index and total new issues each had negative and insignificant impact on GDP.

\section{Material And Methods}

Using a production function approach, it states that the growth rate of output (GDP) is principally determined by the following factors: the rate of growth of gross labour and/or the rate of growth of its quality, multiplied by the labour income share; the rate of growth of gross capital input and/or the rate of growth of its quality, multiplied by the capital income share; and change in technology or total factor productivity (TFP).

This is given as: $\mathbf{Y}=\mathbf{f}(\mathbf{L}, \mathbf{K}, \mathbf{T})$

Where: $\mathbf{Y}=$ growth of GDP

$\mathbf{L}=$ labour

$\mathbf{K}=$ capital formation / investment 
$\mathbf{T}=$ technology

However, GDP is a measure of the contribution of the different sectors to the annual output of goods and services. The sectors include; primary sectors like agriculture and mining; secondary sectors like manufacturing and tertiary sectors like banking. The present study is focused on the agricultural sector. The application of this method, however, has been extended to incorporate other determinants of economic activities in these chosen sectors such as size of the economy (real GDP), infrastructural development (electricity generation) and macroeconomic conditions (inflation and gross capital formation) as well as the variables of interest, capital market indicators which includes market capitalization and All-share index. In line with the above specification, the model is specified thus:

AGDP=f(ELEC,INF,GCF,RDGP,MCR, IND).

The econometric form of the logged model is as given below:

LAGDP $=\left(\alpha_{0}+\alpha_{1}\right.$ LELE $+\alpha_{2}$ INF $+\alpha_{3}$ LGCF $+\alpha_{4}$ LRGDP $+\alpha_{5}$ LMCR $+\alpha_{6}$ LIND $\varepsilon_{t}$

where $\alpha_{0-6}$ are the parameter estimates and $\varepsilon_{t}$ is the error term. The study used econometric methodology of cointegration framework to examine the association between capital market and agriculture growth rate. The estimation was conducted using the econometric computer software package, STATA 11.

\subsection{Definitions and Measurement of Variables}

Agriculture growth rate (LAGDP): agriculture is an important sector of the economy. It is one of the real sectors whose growth has multiplier effects on the economy. The variable used to capture agriculture growth rate is growth rate of agriculture contribution to GDP.

Capital Market Index: the study used two measures of activities in the capital market- market capitalization ratio $(L M C R)$ and All-share index (LIND). These measures are expected to positively impact on the agricultural sector.

Electricity $(\boldsymbol{L E} \boldsymbol{L E})$ : this captures the role infrastructure plays in the enhancing production. The variable is captured by total generation (in mega watt per hour) and it is expected to positively impact on agriculture and the manufacturing sector.

Inflation rate (INF): this is one measure of macroeconomic stability and is an important factor for the attainment of higher economic growth. An improved macroeconomic stability would lead to more incentive for firms and investors to invest and grow the economy. A measure of macroeconomic stability that is employed is the inflation. With a low inflation, there is higher likelihood for more investors showing interest in growing the economy.

Gross capital formation $(\boldsymbol{L G C F})$ : According to the endogenous economic theory, investment provides a positive link to agriculture and manufacturing sector growth.

Real Gross Domestic Product (LRGDP): the variable is used to capture the market size of Nigeria and it is expected to have a positive link with growth of agriculture and manufacturing.

3.2 Data Sources

Annual data with a sample period from 1981 to 2012 was adopted for the study.

The data were obtained from the Central Bank of Nigeria and Nigeria Stock Exchange (NSE) official reports and publications.

\subsection{Unit Root Test}

\section{Presentation Of Results And Analysis}

The summary of the results of the unit root tests conducted using Philip-Perron test is presented in Table 1 below. The decision rule is that we reject the null hypothesis of stationarity if the absolute value of the calculated ADF-statistic is less than the absolute value of the critical ADF-statistic. Otherwise, do not the null hypothesis is rejected.

Source; authors' computation

Table 1: Unit root test

\begin{tabular}{|l|l|l|}
\hline Variable & Test Statistic & Order of Integration \\
\hline LAGDP & $-13.590^{* * *}$ & $\mathrm{I}(0)$ \\
\hline LELE & $-4.443^{* * *}$ & $\mathrm{I}(0)$ \\
\hline LGCF & $-6.117^{* * *}$ & $\mathrm{I}(1)$ \\
\hline INF & $-5.375^{* * *}$ & $\mathrm{I}(1)$ \\
\hline LMCR & $-4.227^{* *}$ & $\mathrm{I}(1)$ \\
\hline LIND & $-4.202^{* *}$ & $\mathrm{I}(1)$ \\
\hline LRGDP & $-3.341^{*}$ & $\mathrm{I}(1)$ \\
\hline KEY: \\
$* * * 1 \%$ critical value \\
$* * 5 \%$ critical value \\
$* 10 \%$ critical value \\
\hline
\end{tabular}


From the above table, it easy to deduce that $\boldsymbol{L A G D P}$ and $\boldsymbol{L E} \boldsymbol{E} \boldsymbol{E}$ were integrated at level form at $1 \%$ critical level, this means that the mean variance and autocovariance of $\boldsymbol{L A G D P}$ and $\boldsymbol{L E} \boldsymbol{E} \boldsymbol{E}$ were constant overtime at level form at $1 \%$ critical level. All the other variables are only stationary after first difference, though LGCF and INF became stationary at $1 \%$ critical value while LMCR and LIND were stationary at 5\% critical value and LRGDP was stationary at $10 \%$ critical value. That is, to say they are all integrated of order one. This means that the mean variance and autocovariance of each series are constant overtime after difference at different critical levels.

\subsection{Co-integration Tests}

Even though individual series in the models above seems not to be stationary at level form, it is possible that their linear combination may be stationary at level form. Hence, they will be co-integrated. That is to say, there exist a long run relationship between the dependent variable and the independent variables. The decision rule is to reject the null hypothesis if the trace statistic is higher than the $5 \%$ critical value, all in absolute terms. The result of the Johansen co-integration test shows that there are at least four co-integrating equations. This is obtained by comparing the trace statistic with the $5 \%$ critical value. The comprehensive result is shown in Table $\mathrm{A}$ at the appendix.

Having determined the existence of a long run relationship, a multiple regression was run to determine the size and magnitude of this relationship. The comprehensive result is at table 2 at the appendix and is interpreted as follows:

ELECTRICITY (LELE): this represents the state and availability of infrastructure and it was expected to have positive impact. Finding from the result confirmed that positive impact is significant at $5 \%$ significant level as a percentage increase in electricity generation will increase agricultural output by $67 \%$.

GROSS CAPITAL FORMATION (LGCF): this did not have the expected relationship. Rather, a percentage increase in capital formation insignificantly reduces agricultural output by $0.54 \%$.

INFLATION RATE (INF): it was expected that inflation rate should have a negative relationship with agricultural output but analysis of the result shows that a percentage increase in inflation rate insignificantly increases agricultural output by $0.16 \%$

REAL GROSS DOMESTIC PRODUCT (LRGDP): from the result, market size represented by GDP, conformed to the a priori expected sign as a percentage increase in real GDP insignificantly increased agricultural output by $85 \%$.

MARKET CAPITALISATION RATIO (LMCR): this is one of the variables of interest representing the capital market size. It was expected to have positive impact on the agricultural sector but the result revealed that when the capital market size increases by one percent, agricultural output reduces insignificantly by $7.1 \%$.

ALL SHARE INDEX (LIND): this is a measure used to capture the mood of the market. The result conformed to the expected relationship as when the all share index increases by one percent, agricultural output increases insignificantly by $13 \%$.

The $\mathrm{F}$ test was used to measure the overall significance of the regression model. The critical value is obtained from the F-distribution table at $5 \%$ level of significance and $(\mathrm{k}-1, \mathrm{n}-\mathrm{k})$ degree of freedom. From the regression result, $\mathrm{F}$-statistic $=19.12$ and at $5 \%$ level of significance, $\mathrm{n}=33$ observations and $\mathrm{k}=5, \mathrm{~F}_{0.05}(5,27) \approx$ 2.56. Since F-statistic $=19.12$ is greater than the critical $F=2.56$, we thereby reject Ho and conclude that the model has a robust fit and it is statistical significant. That means there exist a true relationship between the regression and the regresses.

The $\mathrm{R}^{2}$ measures the goodness of fit of the estimated model. It measures the proportion of total variation in the regress and explained by the regression model. From the regression result the $\mathrm{R}^{2}$ is 0.7797 while the adjusted $\mathrm{R}^{2}$ is 0.7389 . This means that the model explain about $78 \%$ of the total variation in AGDP.

The regression was further subjected to time series specification tests for heteroskedasticity and autocorrelation. The heteroskedasticity test was carried out using Breusch-Pagan/Cook-Weisberg heteroskedasticity. The decision rule is to reject $\mathrm{Ho}$ of no constant variance if $\mathrm{F}$ cal $>\mathrm{F}$ tab at $5 \%$ level of significance; otherwise, do not reject Ho. From the result obtained; Calculated $\mathrm{F}=2.46$, while critical $\mathrm{F}$ at $5 \%$ level of significance $=4.17$. Since calculated $F=2.46$ is less than critical $F(1,31)=4.17$, we therefore do not reject the null hypothesis of homoscedasticity and conclude that the error terms do not have a constant variance.

The Durbin-Watson test was used to test for autocorrelation. The decision rule is to reject Ho that there is no positive autocorrelation at $5 \%$ level of significance if $0<\mathrm{d}<\mathrm{dL}$; otherwise do not reject Ho. From the result obtained, $\mathrm{d}=1.2644$. From the Durbin-Watson table, for 33 observations and 5 explanatory variables, $\mathrm{dL}$ $=1.127$ and $\mathrm{dU}=1.813$ at $5 \%$ level. But since the computed DW lies at 1.2644 which is above dL but below $\mathrm{dU}$, no decision of positive autocorrelation can be taken.

\subsection{Evaluation of the Working Hypothesis and Discussion of Major Findings}

The working hypothesis of this study is restated as follows: 
1. Null Hypothesis $\left(\mathbf{H}_{\mathbf{0}}\right)$ : The Nigerian Capital Market has no growth-inducing impact on the agricultural sector.

2. Null Hypothesis $\left(\mathbf{H}_{\mathbf{0}}\right)$ : The Nigerian Capital Market has no growth-inducing impact on the manufacturing sector.

After rigorously subjecting these hypotheses to various economic, statistical and econometric tests, we hereby present the findings.

The results obtained from the multiple regression validate the null hypothesis. The hypothesis states that the Nigerian capital market has no growth-inducing impact on the agricultural sector. The Nigerian capital market measures had statistically insignificant impact on agricultural output. While the market capitalization ratio had a negative impact on agriculture growth rate, all share index had positive impact on agriculture growth rate.

The result also shows that all the other variables, apart from LELE, individually do not have significant impact on AGDP in the long run. This implies that capital market and other macroeconomic variables (both internal and external) are not robust enough to really have significant growth-inducing impact on the agricultural sector in Nigeria.

The findings of the study show that despite the expanded activities in the Nigerian capital market over the years, there has not been any remarkable impact on the real sectors of the economy represented by the agricultural sector. The banking sub-sector is the most active sector in the Nigerian Stock Exchange. This is followed by the conglomerates sub-sector with the real sectors such as manufacturing and agricultural sector lagging behind. Most of the activities on the floor of the NSE are usually the buying and selling of old stocks with little or no introduction of new shares.

The slump in stock prices as a result of the global economic meltdown in 2008 left many investors and potential investors disillusioned. This resulted in general apathy of investors towards the Nigerian capital market. The global economic meltdown also affected the liquidity of the banks; and as major participants in the equities market, it further worsened the fate of the capital market.

\subsection{Policy Implications}

The findings have the following policy implications:

1. The Nigerian capital market has no growth-inducing impact on the agricultural sector because it is not robust and buoyant enough.

2. The rapid openness of the economy especially through financial liberalisation exposes the capital market to the vagaries of shocks from other developed climes

3. The agricultural sector has not and cannot attract the much needed investment because of many challenges inhibiting the sector, notably the inaccessibility to land for large scale farming.

\section{Conclusion And Recommendations}

Based on the findings of the work, we can confidently conclude as follows:

- The positive and insignificant relationships found suggest that the Nigerian capital market is not buoyant enough to induce growth in the agricultural sector. The finding agrees with Oke and Adeusi, ( 2012 [29]) who found that capital market had a positive impact on economic growth and development of Nigeria. But it has not contributed meaningfully to economic growth and development due to low market capitalization (MCAP), low volume of transaction, and few listed companies on the floor of Nigerian Stock Exchange.

- Secondly, the negative signs obtained in the relationships suggest that the Nigerian capital market lacks depth and breadth as most of them were involved in trading in traditional instruments and in the buying and selling of already existing shares. Also, the level of awareness of Nigerians (especially non- participants) on the existence and potentials of the capital market is low.

- Thirdly, the insignificant relationships reflects the fact that majority of key investors prefer to invest in other sectors such as real estate, jewelries, oil sector etc of the economy other than the capital market.

Based on the findings of the study, the following recommendations were proffered:

- Remove the impediments to the growth of agricultural sector (especial land reforms) to make the sector attractive to potential investors.

- The cost of doing business in Nigeria, particularly in the capital market should be reduced to make it competitive and profitable.

- Policy formulation and implementation should be stabilized, strengthened and transparent

- Foreign investor should be encouraged by government to participate in the market. The government can do this by stabilizing the economy.

- Government should improve basic infrastructures such as communication and information network, electricity, road network. This will ease the cost of doing business and improve the macroeconomic framework. 


\section{References}

[1] Colander, D.C. Economics. New York: McGraw Hill/Irwin, 2004

[2] Andolfatto, D. Macroeconomic Theory and Policy. (A Preliminary Draft), 2005

[3] Schumpeter, J. [1911] 1934. The Theory of Economic Development. Cambridge, Mass.: Harvard University Press.

[4] King, R. G and R. Levine (1993a). Finance and Growth: Schumpeter Might Be Right. Quarterly Journal of Economics, Aug. 1993, 108(3): 717-737

[5] King, R. G and R. Levine. Finance, Entrepreneurship, and Growth: Theory and Evidence. Journal of Monetary Economics, 33, 1993b, 513-542

[6] Goldsmith, R. W. Financial Structure and Development. Yale University Press (New Haven, Conn, 1969).

[7] McKinnon, R. I. Money and Capital in Economic Development. Washington, DC: Brookings Institution, 1973.

[8] Shaw, E. Financial Deepening in Economic Development, New York: Oxford University Press, 1973.

[9] Hicks, J.A. A Theory of Economic History. Clarendon Press (Oxford, U.K), 1969.

[10] Adenuga, A.O. Stock Market Development Indicators and Economic Growth in Nigeria (1990-2009): An Empirical Investigations. Central Bank of Nigeria Economic and Financial Review March 2010: 33-70

[11] Bencivenga, V.R., and B. Smith., and R.M. Starr.. Equity Markets, Transaction Costs, and Capital Accumulation: An Illustration. The World Bank Economic Review, 10, 1996, 241-65.

[12] CBN. Statistical Bulletin, A Central Bank of Nigeria Publications, 2010

[13] Obadan, M, I. Capital Market and Nigeria's Economic Development. A Presidential Address presented at A One-Day Seminar, NES, at the Institute of International Affairs, Lagos, 1998

[14] Nyong M.O. Capital Market Development and Long-Run Economic Growth: Theory, Evidence and Analysis. First Bank Review, 1997, 13-38.

[15] Greenwood, J. and Smith, B. Financial Markets in Development and the Development of Financial Markets. Journal of Economic Dynamics and Control, 1997

[16] Obstfeld, M. Risk-Taking, Global Diversification, and Growth. American Economic Review, December 1994, 84(5), 1994, 13101329 .

[17] Levine, R. Stock Markets, Growth, and Tax Policy. Journal of Finance. 46(4), 1991, 1445-65.

[18] Kyle, A. S. Market Structure, Information, Futures Markets, and Price Formation. In: G.Storey, A. Schmitz, and A.H. Sarris (eds.) International Agricultural Trade: Advanced Readings in Price Formation, Market Structure, and Price Instability Boulder, CO: Westview, 1984

[19] Holmstrom, B. and Tirole, J. Market Liquidity and Performance Monitoring. Journal of Political Economy, 101 (4), 1993, 678709 .

[20] Stiglitz, J. E.. Credit Markets and the Control of Capital. Journal of Money, Credit and Banking , 17(2), 1985, $133-152$.

[21] Demiguc-Kunt, A. and Levine, R. Stock Market Development and Financial Intermediaries: Stylized Facts, World Bank Economic Review, 1996.

[22] Jensen, M. C., and Murphy, K. J. Performance Pay and Top-Management Incentives. The Journal of Political Economy, 98(2), $1990,225-264$.

[23] Kolapo, F.T and Adaramola, A.O . The Impact of the Nigerian Capital Market on Economic Growth (1990-2010). International Journal of Developing Societies 1(1), 2012, 11-19.

[24] Usman, O.A. The Role of Capital Market on Economic Growth in Nigeria (1980-2008). Research Journal of Finance and Accounting 2(3), 2011, 35-47

[25] Ihendinihu, J.U and Onwuchekwa, J.C. Stock Market Performance and Economic Growth in Nigeria 1984-2011. Journal of Emerging Trends in Economics and Management Sciences 3(6), 2012, 971-977

[26] Barna, F and Mura, P.O . Capital Market Development and Economic Growth: The Case of Romania. Annals of the University of Petroşani, Economics, 10(2), 2010, 31-42

[27] Brasoveanu, L.O; Dragota, V, Catarama, D and Semeneseu, A. Correlation between Capital Market Development and Economic Growth: the case of Romania. Journal of Applied Quantitative Methods 3(1), 2008, 64-75.

[28] Donwa, P and Odia, J. An Empirical Analysis of the impact of Nigerian Capital Market on her socio Economic Development. Journal Social Science, 24(2), 2010, 135-142.

[29] Oke, M.O and Adeusi, S.O. Impact of Capital Market Reforms on Economic Growth: The Nigerian Experience. Australian Journal of Business and Management Research, 2(2) 2012, 20-30

\section{Appendix}

$\begin{array}{lc}\text { Table A: } & \text { Johansen tests for cointegration } \\ \text { Trend: constant } & \begin{array}{c}\text { Number of obs }= \\ \text { Lags }=\end{array} \\ \text { Sample: } 1982-2012 & 2\end{array}$

$\begin{array}{cccccc}\begin{array}{c}\text { maximum } \\ \text { rank }\end{array} & \text { parms } & \text { LL } & \text { eigenvalue } & \begin{array}{c}\text { trace } \\ \text { statistic }\end{array} & \begin{array}{c}5 \% \\ \text { critical } \\ \text { value }\end{array} \\ 0 & 56 & -9.3094372 & . & 196.6330 & 124.24 \\ 1 & 69 & 24.823966 & 0.88944 & 128.3662 & 94.15 \\ 2 & 80 & 46.935787 & 0.75987 & 84.1426 & 68.52 \\ 3 & 89 & 61.256586 & 0.60304 & 55.5010 & 47.21 \\ 4 & 96 & 73.202525 & 0.53731 & 31.6091 & 29.68 \\ 5 & 101 & 82.059906 & 0.43529 & 13.8943 * & 15.41 \\ 6 & 104 & 86.424763 & 0.24543 & 5.1646 & 3.76 \\ 7 & 105 & 89.007066 & 0.15346 & & \end{array}$




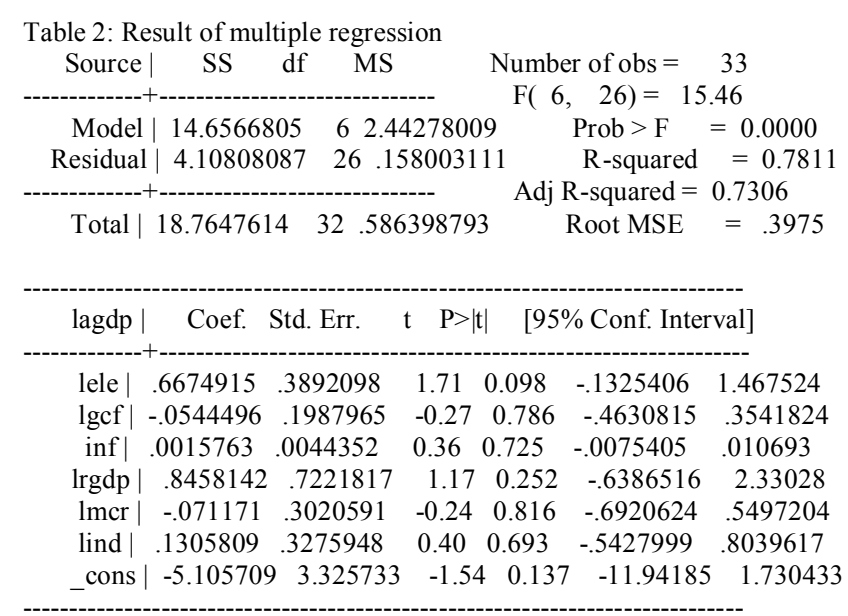

. estat dwatson

Durbin-Watson d-statistic $(7, \quad 33)=1.207822$

. estat hettest, fstat

Breusch-Pagan / Cook-Weisberg test for heteroskedasticity

Ho: Constant variance

Variables: fitted values of lagdp

$\mathrm{F}(1,31)=2.53$

Prob $>\mathrm{F}=0.1219$ 